\title{
DISCRETIONARY EXCEPTION UNDER FEDERAL TORTS CLAIMS ACT: SOVEREIGN IMMUNITY \\ DIES A SLOW DEATH*
}

IN RECENT years, the ancient doctrine of sovereign immunity ${ }^{1}$ has been steadily eroded by legislative limitations, the most significant and recent of which, the Federal Torts Claims Act of $1946,{ }^{2}$ generally seeks to equate the tort liability of the federal government with that of a private individual. This seemingly broad waiver of immunity, however, is conditioned, inter alia, by the proviso that governmental liability may not be predicated on the negligent performance or non-performance of a discretionary function or duty by one of its employees. ${ }^{3}$ What constitutes a "discretionary function or duty," however, has become shrouded in a mystery which the Supreme Court has deepened rather than dispelled in the recent case of Dalehite v. United States. ${ }^{4}$

In this case, two ships carrying Fertilizer Grade Ammonium Nitrate (FGAN), manufactured under the aegis of the United States Government ${ }^{5}$ and destined for Europe, exploded in the harbor at Texas City, Texas, with great resultant loss of life and property. ${ }^{6}$ The petitioners, alleging negligence in the coating, bagging, labelling, and shipping of the FGAN as the proximate cause of the disaster, brought action under the Federal Torts Claims Act to recover for the death of one Dalehite. An award of damages by the District Court was unanimously reversed

* Dalehite v. United States, 346 U.S. 15 (1953).

${ }^{1}$ See Holdsworth, The History of Remedies Against the Crown, 38 L. Q. REv. 141 (1922); Barry, The King Can Do No Wrong, II VA. L. REv. 349 (1925).

260 STAT. 842,28 U.S.C. $\$ \S 921-946$ (1946).

${ }^{3}$ 6o STAT. 845,28 U.S.C. $\$ 943$ (a) (1946) excepts: "Any claim based upon an act or omission of an employee of the Government, exercising due care, in the execution of a statute or regulation, whether or not such statute or regulation be valid, or based upon the exercise or performance or the failure to perform a discretionary function or duty on the part of a federal agency or an employee of the Government, whether or not the discretion involved be abused."

346 U.S. 15 (1953).

${ }^{6}$ Exec. Order 9347, May 27, 1943, 8 FEd. REg. 7207, U. S. Cong. Service, pp. 5-48. The manufacture of the FGAN was carried on under the direction of the Army's Field Director of Ammunition Plants. FGAN is composed primarily of Ammonium Nitrate, an ingredient long used in the manufacture of explosives.

'See N.Y. Times, Apr. 17, 1947, p. 1, col. 8 for description of the extent of the explosion and damages. 
by the Circuit Court of Appeals, ${ }^{7}$ which was upheld on certiorari by a divided Supreme Court. ${ }^{8}$

Both appellate courts denied recovery on the sole ground that, in terms of the Torts Claims Act itself, the claim was one "based upon the exercise or performance or failure to exercise or perform a discretionary function or duty on the part of a federal agency or an employee of the government, ${ }^{\prime \prime}$ and found it unnecessary to consider the problem of negligence. Mr. Justice Reed, speaking for the majority, said that, inasmuch as the acts of negligence alleged consisted of decisions made at levels of high policy, they were within the exception, and were not properly amenable to judicial redress under the Act. ${ }^{10} \mathrm{Mr}$. Justice Jackson, however, in a strong dissenting opinion in which he was joined by Messrs. Justices Black and Frankfurter, urged that the decisions complained of were not "discretionary" within the meaning of the Actthat once the decision to undertake the project was made, the government was bound to exercise due care in its execution. ${ }^{11}$

Previous cases dealing with the "discretionary" exception have not clearly defined its scope. ${ }^{12}$ On the one hand it appears to be fairly well settled that the government is exempted from liability for negligence in such activities as irrigation, navigation, and flood control. ${ }^{13}$ It is significant, however, that the complaints in these cases seem principally to have been directed against acts done under an express grant of discretion by Congress, as was the case in Boyce v. United States, ${ }^{14}$ where the allegedly negligent acts were committed pursuant to a plan for deepening the channel of the Mississippi River. Moreover, the legis-

${ }^{7}$ In re Texas City Disaster Litigation, 197 F.2d 771 (5th Cir. 1952).

${ }^{8} 346$ U.S. 15 (1953).

- Suppra note 3 .

10346 U.S. 15,33 (1953).

${ }^{11}$ Id. at 47 . This was also substantially the position of Judge Strum, concurring specially in the decision of the Circuit Court of Appeals. In re Texas City Disaster Litigation, 197 F.2d 771 (5th Cir. 1952).

${ }_{12}$ E.g., Compare Toledo v. United States, 95 F. Supp. 838 (D. Puerto Rico 195 I) with Somerset Seafood Co. v. United States, I93 F.2d 63I (4th Cir. 1950).

${ }^{13}$ Coates v. United States, 18 I F.2d 8 I 6 (8th Cir. 1950) (damages resulting from acts done pursuant to a plan for changing the course of the Missouri River); Thomas v. United States, 8 I F. Supp. 88I (W.D. Mo. 1949) (damages resulting from flood control operations carried on under the direction of the Chief of Engineers of the War Department); Olson v. United States, 93 F. Supp. 120 (D. North Dakota 1950) (damages resulting from the opening of the flood gates of a dam when the regular channel of the river was blocked by ice and snow); North v. United States, 94 F. Supp. 824 (D. Utah 1950) (damages resulting from overflows occurring in the course of an irrigation project).

${ }^{14} 93$ F. Supp. 866 (S.D. Iowa 1950). 
lative history of the Act clearly reveals an intent that the exception embrace such projects. ${ }^{15}$

On the other hand, in another broad class of cases-that of claims growing out of the alleged negligence of officials of government hospitals-the asserted immunity is not so frequently respected. ${ }^{10}$ While it has been held that the admission of a patient is a discretionary decision within the exception, it has repeatedly been held that once the patient is admitted, due diligence and care must be exercised in treating him. ${ }^{17}$ This would seem generally to reflect some tendency by the courts to recognize a distinction between the wide range of discretion permissible at the inception of governmental undertakings and the narrower range permissible in details of execution closely touching the safety of individuals, once the undertaking has been assumed.

On its face the language of the exception leaves room for great flexibility of interpretation. An attempt to minimize this ambiguity was made in Coates v. United States, ${ }^{18}$ where it was held that "discretionary function" should be construed under the Act as it generally is in other contexts. There are, however, two objections to this course. First, "discretionary" has never acquired any clear, unequivocal legal content applicable to all situations. ${ }^{19}$ Second, one may question the wisdom of applying to this exception the definitions of "discretionary" suitable in other contexts in which the term is susceptible of a broader interpretation than seems necessary or desirable under the Act, e.g., questions involving mandamus or personal liability of officials. ${ }^{20}$ Nevertheless, the courts currently incline to favor the views expressed in the Coates case, ${ }^{21}$ a consequence forseen by some while the Act was still in its infancy. ${ }^{22}$

${ }^{15}$ H. R. REP. No. 1287 , 79th Cong., rst Sess. (1946). This report explicitly states that it is intended that irrigation and flood control projects should come within the purview of the exception.

${ }^{18}$ E.g., Denny v. United States, 171 F.2d 365 (5th Cir. 1948) (no liability for the refusal to admit parturient wife of Army officer).

${ }^{17}$ Costley v. United States, 18 I F.2d 723 (5th Cir. r950) (government held liable when patient injured by injection of a harmful solution instead of a spinal anesthesia at army hospital); Grigalauskas v. United States, ro3 F. Supp. 543 (D. Mass, 1951) (government held liable for injury to patient when an army doctor administered a concentrated solution rather than the diluted solution called for on the label); United States v. Gray, 199 F.2d 239 (roth Cir. 1952) (government held liable for negligent treatment of a mental patient).

${ }^{28}$ I 8I F.2d 816 (8th Cir. 1950). See note 13 stupra.

${ }^{10}$ It is said that the difference between discretionary and non-discretionary is largely a matter of degree. Patterson, Ministerial and Discretionary Official Acts, $20 \mathrm{MicH}$.

L. REv. 848,886 (1922).

${ }^{20}$ Note, 66 Harv. L. REv. 488, 495 (1953).

${ }^{21}$ See note, 19 A.L.R. 2d 840 (1951).

${ }^{22}$ Note, 37 GEO. L.J. 646,647 (1949). "Just how far this exemption from liabil- 
If the Coates rationale is not acceptable, what alternatives exist? In Federal Housing Administration v. Burr the Court said, "We start from the premise that such waivers by Congress of governmental immunities ... should be liberally construed. This policy is in line with the current disfavor of the doctrine of governmental immunity from suit. ....23 Also, in United States v. Aetna Casualty and Surety Co. ${ }^{24}$ the Court adopted the words of Judge Cardozo in Anderson v. John L. Hayes Construction Co.: "The exemption of the sovereign from suit involved hardship enough where consent had been withheld. We are not to add to this rigor by refinement of construction where consent has been announced."25 However, in Kendrick v. United States ${ }^{26}$ it was stated that the exception should be construed in favor of the government, a view which seems to prevail among the federal district courts. ${ }^{27}$

The legislative history of the Torts Claims Act would seem to impel adoption of an interpretation along the lines indicated by Judge Cardozo. ${ }^{28}$ Long before passage of the Act there was general discontent with the doctrine of sovereign immunity from tort liability.9 This discontent found expression in Congressional consent to liability in various limited areas ${ }^{30}$ and loomed very large in the deliberations preceding the present Act. ${ }^{31}$ The only existing procedure for redressing substantial tort claims against the government was by means of private congressional bills, a system which resulted in a disproportionate em-

ity will be extended by the courts is highly speculative. . . . If the courts should so desire to extend exemption from liability, they could do so by applying the common law definition of discretionary." Also, Judge Hulen, in an address before the St. Louis section of the Missouri Bar Association, reprinted in 7 F.R.D. 689, 693 (r948), said, "Frankly, it appears to me the exemption is broader than the declared purpose. This law is marking the course on a heretofore unchartered sea and many of its provisions may require clarification by Congress or the courts."

${ }^{23} 309$ U.S. 242,245 (1 940$)$.

24338 U.S. 366,383 (1949).

25243 N.Y. $140,147,153$ N.E. 28,29 (1926).

${ }^{20} 82$ F. Supp. 430 (N.D. Ala. 1949).

${ }^{27}$ E.g., Boyce v. United States, 93 F. Supp. 866 (S.D. Iowa 1950) (See text sulpra.); Toledo v. United States, 95 F. Supp. 838 (D. Puerto Rico I95I) (duties of federal employee in maintaining trees at agricultural experimental station held to be discretionary).

${ }^{28}$ See note 26 supra and accompanying text.

${ }^{20}$ Gottlieb, Tort Claims A Aainst the United States, 30 GEo. I. REv. 462 (194.2).

${ }^{30}$ Patent infringements, 36 STAT. 851 (1910), 35 U.S.C. $\$ 68$ (1946); admiralty and maritime claims, 4I STAT. 525 (1920), 46 U.S.C. $\$ 74 \mathrm{I}$ (1946); small tort claims, 42 STAT. 1066 (1922), repealed by 60 STAT. 846 (1946).

32 "The survival of government irresponsibility in the field of torts is an anachronism founded on no sounder reason than a historical prejudice against tort claims." Hearings Before the House Committee on Judiciary on H.R. No. 5373 and H.R. No. $\sigma_{4} \sigma_{3}$, 77th Cong., $2 d$ Sess., p. 42 (I942). 
phasis upon relatively inconsequential matters when important legislation was pressing. ${ }^{32}$ Aware of these factors and feeling, moreover, that the courts were better suited than Congress to pass on the merits of private claims, the Joint Committee on the Organization of Congress recommended that all such claims be transferred by law to the district courts and the Court of Claims. ${ }^{33}$ The Act of 1946, based on this report, would seem, therefore, to require an interpretation that would extend its operation to the broadest extent consistent with the fair meaning of its language.

In this light, the decision in the instant case seems to restrict the compass of the Act unnecessarily. The Court infers that the negligent acts complained of were "discretionary" (and hence immune) from the fact that they were directed from high policy levels. ${ }^{34}$ Whether an act or function is "discretionary," however, should rather be determined by exploring the nature of the act itself-not merely by referring to the status of the actor. Were this not so, every tortious action of a high governmental official would be immune from judicial inquiry without regard to its nature or consequence.

Granting, then, that the criterion for deciding whether or not an act is "discretionary" depends on the nature of the act itself, this determination must be made in the light of the purpose of the exception. The Report of the House Committee on the Judiciary of the $77^{\text {th }}$ Congress stated that the section was:

... designed to preclude application of the bill to a claim against a regulatory agency, such as the Federal Trade Commission or the Securities and Exchange Commission, based on an alleged abuse of discretionary authority by an officer or employee, whether or not negligence is alleged to have been involved. (emphasis added) ${ }^{35}$

There is clearly discernible in this statement the well-settled policy of safeguarding the free and courageous exercise of administrative judgment from the threat of private suit. It is seriously to be doubted, however, whether such a policy is applicable to a decision concerning the temperature at which a government manufactured product shall be packaged. The above comment by the committee obviously contemplates immunity for the government when it is acting in a regulatory, or purely governmental capacity. This is in no way repugnant

${ }^{32} I d$. at 40 . (About 2000 private relief bills were introduced into each session of Congress prior to the Act.)

${ }^{33}$ SEN. REP. No. 2245, 77th Cong., 2d Sess. (1942).

34 U.S. 15,33 (1953).

${ }^{35}$ H.R. REP. No. 2245, $77^{\text {th }}$ Cong., $2 d$ Sess. (1942). 
to the underlying philosophy of the Act, for it could not be expected that regulatory decisions should be left open to private attack. But when the government is acting as manufacturer or shipper, its function is at best only remotely governmental, and to grant it immunity in such activities would be inconsistent with the basic premise of the Act, which is that the government should be answerable in damages "respecting the provisions of this title relating to tort claims, in the same manner and to the same extent as a private individual under like circumstances."36 The reasons for distorting the meaning of the exception so as to exempt the government in the instant case are not readily apparent.

This decision renders the extent of governmental liability under the Act even more speculative than when it was first passed. ${ }^{37}$ Insofar as the discretionary exception is here applied to non-regulatory functions, the "sky is now the limit" in restricting the scope of the Act. ${ }^{38}$ This is not only irreconcilable with the legislative history of the exception, but it also frustrates the avowed purpose of the Act. One cannot ignore the misgivings expressed by the dissenters in the present case: "Surely a statute so long debated was meant to embrace more than traffic accidents. If not, the ancient and discredited doctrine that 'The King can do no wrong' has not been uprooted; it has only been amended to read, 'The King can do only little wrongs.' "39

Clarence Walker

\footnotetext{
${ }^{30} 60$ STAT. 844,28 U.S.C. $\$ 931$ (1946).

${ }^{37}$ See note $2 \mathrm{x}$ supra.

${ }^{38}$ See notes $3 \mathrm{I}-33$ supra.

${ }^{\text {a9 }} 346$ U.S. 15,60 ( 1953$)$.
} 